\title{
UM OLHAR RETROSPECTIVO
}

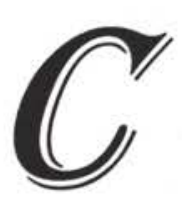

inco séculos de história do Brasil já dobraram página. Muitos olhares revisitaram cenas e cenários do passado. Nós também nos propusemos a fazer o mesmo desde a ótica das migrações. Perseguimos a tentativa de um balanço qualitativo a partir de diferentes ângulos. Não alcançamos montar o caleidoscópio pretendido, no entanto, alguns espelhos foram dispostos.

O primeiro, apresentado por Gallois - onde o foco recai sobre os legitimos donos dessa terra/Brasil exibe, não um desfile de imagens marcadas pela mobilidade a eles imposta desde a chegada do estranho, mas uma síntese que aponta para desafios advindos da transformação em curso do perfil das sociedades indigenas. É complexo o pano de fundo donde brotam as reflexões, mas é nítida sua projeção.

O segundo, pelas mãos de Consorte, reflete uma das facetas da herança deixada pelos 4 milhões de negras e negros aqui trazidos como mercadoria - a do sincretismo. Traz à tona um ingrediente novo. Após 500 anos marcados por uma dupla pertença, alguns expoentes dos cultos afro brasileiros empunharam, em favor do resgate da africanidade do candomblé, o fim do sincretismo. O que de fato isso representa?

O terceiro, emoldurado por Vainer, abarca as intervençóes do Estado nacional no tocante à mobilização e localização de populações. Faz observar como as políticas migratórias, que durante um largo periodo de tempo estiveram voltadas para o pre enchimento dos espaços vazios, transmutam se em ações para a sua desocupação; mostra como a população, considerada precioso recurso, transforma -se em ônus; de nuncia que aos tornados excedentários, durante um século mobilizados com a pro messa da integração, acena-se hoje apenas com ações sociais fragmentadas, quando não com a violência. E, frente a semelhante quadro, conclui que tanto os migrantes candidatos às politicas sociais, quanto os que passaram a deixar o Brasil nas duas últimas décadas, constituem a mais contundente denúncia de um país que abdicou de um projeto próprio.

O quarto espelho, trabalhado a duas mãos, por Sales e Baeninger, projeta uma síntese dos principais deslocamentos de populações nos últimos cem anos, com desta que para as novidades que vêm ocorrendo nesse final de milênio: o novo perfil da migração interna; a emigração de brasileiros e a imigração de latino-americanos, em especial bolivianos, além dos coreanos e em menor número de africanos.

O último, moldado por Seyferth, retrata as discussões acerca da assimilação, ora vinculadas ao nacionalismo, ora dele descoladas, mas incapazes de dar conta da persistência das diferenças. Faltou, aos estudiosos da assimilação, ultrapassaro horizonte da mobilidade social, para, além dele, ir de encontro ao conceito de etnicidade.

\section{Dirceu Cutti}

